\title{
Down regulation of Ia expression in macrophages following incubation with mycobacteria
}

\author{
Yasuo Fukutomi ${ }^{*}{ }^{*}$, Satoko Inui ${ }^{2}$, Kikuo Onozaki ${ }^{3)}$, Yasuko Yogi ${ }^{1)}$, \\ and Fumishige Minagawa ${ }^{1)}$
}

\begin{abstract}
1) National Institute for Leprosy Research, Tokyo Japan.
2)Department of Microbiology, Institute of Basic Medical Sicences, The University of Tsukuba, Japan.

3)Department of Hygienic Chemistry, Faculty Pharmaceutical Sciences, Nagoya City University, Japan.
\end{abstract}

key words: macrophage, IL-1, TNF, Ia, mycobacteria

Macrophages are known to release cytokines in response to various kinds of stimulators. In the present study, peritoneal macrophages from $\mathrm{C} 3 \mathrm{H} / \mathrm{He}$ or $\mathrm{C} 3 \mathrm{H} / \mathrm{HeJ}$ mice were incubated in vitro with heat-killed $M$. lepraemurium, $M$. intracellulare or $M$. gordonare for 3 days followed by harvest culture supernatant to analyze cytokine activities. It, therefore, seems that macrophages phagocytizing these mycobacteria, released interleukin-1 (IL-1) and tumor necrosis factor (TNF) in culture media. The amount of release was dose dependent on mycobacteria employed. In addition, macrophages, as already have reported elsewhere, treated with IFN for 2 to 3 days showed enhanced expression of surface Ia; although the expression was inhibited if the cells phagocytized mycobacteria. Similarly, the reduced expression of Ia was observed in peritoneal macrophages from MRL/ $/ p r$ mice after 3 dayculture with mycobacteria in vitro. More importantly, in the presence of the supernatant obtained from macrophages incubated with mycobacteria, IFN $\gamma$-treated normal macrophages exihibited suppressed expression of Ia.

These results demonstrate that cytokine release and reduced expression of surface Ia in macrophages are simultaneous phenomena after phagocytosis of mycobacteria. Suppression of Ia may be in part induced by Ia suppressive factor(s) released from mycobacteriumphagocytized macrophages.

Macrophages are defined as large mononuclear, phagocytic cells. In mycobacterial infections including leprosy, mycobacteria can invade and replicate within macrophages ${ }^{(1)}$.

*Corresponding author:

Address: National Institute for Leprosy Research, 2-1,4chome, Aoba-cho, Higashimurayama-shi, Tokyo 189, Japan.
Concerining about immunity, macrophages play an important role in immune response by production of cytokines such as interleukin 1 and tumor necrosis factor, and by presentation of fragmented-antigen to $\mathrm{T}$ cells through class II (Ia) molecule on their cell surface ${ }^{(2,3)}$. Both production of cytokines and enhanced expression of Ia in macrophages are generally thought 
to be related to up-regulated immune response. We report here the production of interleukin 1 and TNF, and reduced expression of Ia in macrophage during the course of incubation with mycobacteria; these observations would be closely involved in immune response of a host against mycobacteria.

\section{MATERIALS AND METHODS}

Mice. Male or female $\mathrm{C} 3 \mathrm{H} / \mathrm{He}$ and $\mathrm{C} 3 \mathrm{H} / \mathrm{HeJ}$ mice, 2 or 3 months old were used. MRL/lpr mice were initially purchased from Central Institute for Experimental Animals (Kawasaki city, Kanagawa, Japan) and were maitained at our institute.

Mycobacteria. M. lepraemurium (Hawaii strain) were obtained from log-phase growth in nude mice. $M$. intracellulare (ATCC 15769) and $M$. gordonare (ATCC 14470) were grown in Dubos medium (Eiken, Tokyo, Japan). These mycobacteria were washed extensively with PBS, autoclaved for $5 \mathrm{~min}$ at $121^{\circ} \mathrm{C}$, resuspended in PBS, and stored at $4^{\circ} \mathrm{C}$ until use.

Culture of macrophages. Peritoneal exudate cells were obtained from $\mathrm{C} 3 \mathrm{H} / \mathrm{He}$ or $\mathrm{C} 3 \mathrm{H} / \mathrm{HeJ}$ mice injected intraperitoneally with $2-3 \mathrm{ml}$ of thioglycollate medium (Difco laboratories, Detroit, MICH, USA) 4 days before harvest. After harvest with Hanks buffered salt solution (HBSS, Nissui, Tokyo, Japan), $5 \times 10^{6}$ cells were cultured in RPMI1640 (Nissui) $-5 \%$ heatinactivated fetal bovine serum (FBS, BioWhittaker, Inc., Walkersville, MD, USA) supplemented with $15 \mathrm{mM}$ HEPES (pH 7.2), $2 \mathrm{mM}$ of L-glutamine, $100 \mathrm{U} / \mathrm{ml}$ of penicillin and 100 $\mu \mathrm{g} / \mathrm{ml}$ of streptomycin for 2 to $3 \mathrm{hr}$ in 12 -well culture plates (Linbro, Flow Laboratories Inc., Mclean, VA, USA) or $60 \mathrm{~mm}$ dishes (Sumilon, Sumitomo Bakelite Co., Ltd., Tokyo, Japan). Non adherent cells were removed by washing with HBSS. Resulting adherent cells were then incubated for 3 days in the presence of heat- killed mycobacteria and cell-free culture supernatant was obtained by centrifugation. After dialysis of the supernatant against RPMI1640 in a dialysis tube (Spectrapore No.3, molecular weight cut off at 3,500, Spectrum Medical Industries Inc., LA, CA, USA), filtration through 0.45 micron filter (Acrodisc, Gelman Sciences, Ann Arbor, MI, USA) was performed for analysis of IL-1 and TNF activities. Similarly, peritoneal resident cells from MRL/lpr mice, 3 months old in a progessing disease state, were harvested and incubated in $35 \mathrm{~mm}$ petri dishes for Ia analysis.

Assay for IL-1 activity. IL-1 activity in the supernatant of macrophage-cultures was determined by enhancement of thymocyte proliferation in the costimulator assay ${ }^{(4)}$. One point five million of thymocytes from $\mathrm{C} 3 \mathrm{H} / \mathrm{HeJ}$ mice were cultured in 96-well plates (No.3596, Costar, Cambridge, MA, USA) in the presence of supernatant and $0.5 \mu \mathrm{g} / \mathrm{ml}$ of concanavalin A (Sigma chemical Co., St. Louise, MO, USA). Cultures incubated for a total $72 \mathrm{hr}$ and pulsed with $0.5 \mu \mathrm{Ci}$ of $\left[{ }^{3} \mathrm{H}\right]$-thymidine $18 \mathrm{hr}$ before harvest cells. After collecting cells onto a glass fiber membrane, the incorporated radioactivity was counted by a liquid scintillation counter. One unit of $\mathrm{IL}-1 / \mathrm{ml}$ was determined as the concentration of the supernatant necessary to produce half-maximum incorporation of radioactivivty.

Assay for TNF activity. The activity of TNF in supernatant was determined by a modified L929 fibroblast cell lytic assay (5). Briefly, $3 \times 10^{4}$ of TNF-sensitive mouse L929 fibroblast cells were cultured with diluted macrophage supernatant in the presence of 1 $\mu \mathrm{g} / \mathrm{ml}$ of actinomycin D (Sigma) in a well of a 96 -well plate for $24 \mathrm{hr}$ at $37^{\circ} \mathrm{C}$. After culture, medium in the plate was discarded by inversion and flicking the plate. The cells adhering to the wells were then stained with $0.1 \%$ of crystal violet and solubilized by $1 \%$ SDS solution foll- 
owed by measurement of absorbance at $570 \mathrm{~nm}$ with a spectrophotometer (Titertek Multiscan Type, Flow Labs, Stanmore, NSW, Australia). The cytotoxic activity of TNF in units per $\mathrm{ml}$ was defined as the reciprocal of the dilution resulting in $50 \%$ cytotoxicity.

Ia analysis. Peritoneal resident or exudate cells were incubated in $35 \mathrm{~mm}$ petri dishes for 2 $\mathrm{hr}$, and non-adherent cells were removed by washing. Adherent cells were then cultured in the presence of IFN gamma (gift from Torei, Tokyo, Japan) for 3 days, recovered from dishes with rubber policeman and stained for Ia by using a monoclonal anti- $\mathrm{Ia}^{\mathrm{k}}$ antibody (Becton Dickinson Immunocytometry Systems, Mountain view, CA, USA) and fluorescence conjugated $\mathrm{F}\left(\mathrm{ab}^{\prime}\right)_{2}$ fragments of goat antimouse IgG antibody (BioSource International Inc., Camarillo, CA, USA). Fluorescence intensity of the cells was analyzed on flow cytometry systems (FCS-1 of Japan spectroscopic Co.,Ltd., Tokyo, Japan and FACScan of Becton Dickinson Immunocytometry Systems) .

LK preparation. Spleen cells were obtained from spleens of normal $\mathrm{C} 3 \mathrm{H} / \mathrm{He}$ mice. Briefly, spleens were obtained aseptically, minced by frost glasses, treated with $0.83 \%$ of $\mathrm{NH}_{4} \mathrm{Cl}$ to lyse red cells, centrifuged and resusupended in serum-free RPMI1640 containing $15 \mathrm{mM}$ HEPES (pH 7.2), 100U/ml of penicillin and 100 $\mu \mathrm{g} / \mathrm{ml}$ of streptomycin in the presence of 50 $\mathrm{mM}$ of 2-mercaptoethanol. The cells were cultured in the presence of $2 \mu \mathrm{g} / \mathrm{ml}$ of concanavalin A (Sigma). After 3 days, cell-free supernatant was harvested followed by mixing with Sepharose G-10 (Farmacia Chemicals, Uppsala, Sweden) and incubated for $3 \mathrm{hr}$ by rotating at $4^{\circ} \mathrm{C}$. The preparation was centrifuged again to remove sepharose particles and dialyzed against RPMI1640. This final preparation was used as a lymphokine-containing supernatant (LK).

Assay for glucose consumption by macro-
phages.Glucose consumption assay was performed by the methods as described previously ${ }^{(6)}$. After incubation of macrophages in medium, 20 $\mathrm{ml}$ aliquots of the supernatant were harvested, and glucose content was assessed using a "Glucose-B-test-Wako" kit (Wako Chemicals, Osaka, Japan) which consists of glucose oxidase and so on. A macrophage activation index based on glucose utilization was calculated as: MA index $=(\%$ of glucose remaining in test sample $) \div(\%$ of glucose remaining in control sample).

\section{RESULTS}

Cytokine activities in supernatants harvested from macrophages incubated with mycobacteria.

Table 1. IL-1 and TNF production by mouse peritoneal exudate macrophages ${ }^{a}$

\begin{tabular}{ccc}
\hline $\begin{array}{l}\text { Macrophages } \\
\text { incubated with }\end{array}$ & $\begin{array}{l}\mathrm{IL}-1 \text { activity } \\
\mathrm{U} / \mathrm{ml}^{\mathrm{b}}\end{array}$ & $\begin{array}{l}\mathrm{TNF} \text { activity } \\
\mathrm{U} / \mathrm{ml}^{\mathrm{c}}\end{array}$ \\
\hline $\begin{array}{c}\text { M.lepraemurium, } \\
8 \mu \mathrm{g} / \mathrm{dish}\end{array}$ & $<1$ & $<1$ \\
40 & $<1$ & $<1$ \\
200 & $<1$ & $<1$ \\
1,000 & 7.5 & 13.0 \\
M.intracellulare, & & \\
8 & $<1$ & $<1$ \\
40 & $<1$ & $<1$ \\
200 & $<1$ & 1.8 \\
1,000 & 11.6 & 14.8 \\
M.gordonare, & & $<1$ \\
8 & $<1$ & $<1$ \\
40 & $<1$ & $<1$ \\
200 & $<1$ & 6.7 \\
1,000 & 4.8 & $<1$ \\
\hline
\end{tabular}

a Macrophages were incubated with heat-killed mycobacteria for 3 days, then IL-1 anc TNF activities in the supernatants were analyzed.

${ }^{\mathrm{b}}$ The activity of IL-1 was measured by a thymocyte proliferation assay.

${ }^{\mathrm{c}}$ The activity of TNF was measured by a L929 cell lytic assay.

Mouse peritoneal exudate macrophages were incubated in the presence of heat-killed $M$. 
lepraemurium, $M$. intracellulare or $M$. gordonare for 3 days, and cell-free culture supernatants were harvested. IL-1 and TNF activities in them were analyzed after dialysis against RPMI1640 medium.

As shown in table 1, enhanced IL-1 and TNF activities were observed in each supernatant. The results also indicated that the significant enhancement of cytokine production was observed in a dose dependent fashion of the mycobacteria employed. By acid-fast staining and observation under microscopy, macrophages incubated with mycobacteria showed many ingested bacteria inside.

Glucose consumption by macrophages following incubation with mycobacteria. Before dialysis, aliquot of the supernatant was served for measurement of glucose content by a colorimetric assay.

Table 2. Enhanced glucose consumption by mouse peritoneal exudate macrophages ${ }^{a}$

\begin{tabular}{cll}
\hline $\begin{array}{l}\text { Macrophages } \\
\text { Incubated with }\end{array}$ & $\begin{array}{l}\text { Glucose } \\
\text { content }^{\mathrm{b}}\end{array}$ & $\begin{array}{l}\text { MA } \\
\text { index }^{\mathrm{c}}\end{array}$ \\
\hline $\begin{array}{c}\text { M.lepraemurium, } \\
8 \mu \mathrm{g} / \mathrm{dish}\end{array}$ & $0.827 \pm .024$ & 0 \\
40 & $0.746 \pm .012$ & 8 \\
200 & $0.596 \pm .007$ & 26 \\
1,000 & $0.319 \pm .008$ & 61 \\
M.intracellulare, & & \\
8 & $0.766 \pm .022$ & 5 \\
40 & $0.689 \pm .024$ & 15 \\
200 & $0.488 \pm .012$ & 40 \\
1,000 & $0.398 \pm .008$ & 51 \\
M.gordonare, & & \\
8 & $0.728 \pm .012$ & 10 \\
40 & $0.699 \pm .024$ & 14 \\
200 & $0.485 \pm .006$ & 40 \\
1,000 & $0.481 \pm .009$ & 41 \\
Medium & $0.810 \pm .053$ & \\
\hline
\end{tabular}

${ }^{a}$ Macrophages were incubated with heat-killed mycobacteria for 3 days, ihen the supernatants were collected and assessed for glucose content.

${ }^{\mathrm{b}}$ Absorbance at $490 \mathrm{~nm}$ by an enzyme assay.

${ }^{\mathrm{c}}$ Macrophage Activation index.

As shown in table 2, glucose content in medium decreased with the increased amount of mycobacteria employed in culture, indicating the utilization of glucose by macrophages was enhanced in a dose dependent manner by the mycobacteria present in culture.

Inhibited Ia expression in macrophages which phagocytized mycobacteria. Normal peritoneal macrophages were incubated with mycobacteria and Ia expression on the cell surface was analyzed by flow cytometries. At 3 day incubation of macrophages with heatkilled mycobacteria, cells were recovered from the dishes by scraping off with rubberpoliceman. The cells were then stained with mouse anti- $\mathrm{Ia}^{\mathrm{k}}$ antibody and FITC-labelled goat anti-mouse $\mathrm{Ig}$ followed by analysis of fluorescence intensity. The results are shown in table 3 in the form of the mean fluorescence intensity. By drawing profiles of the results with 2nd antibody staining as a staining background, in normal cells, about $15 \%$ population was Ia positive from a total number of cells

Table 3. la antigen expression in macrophages by incubation with mycobacteria ${ }^{a}$

\begin{tabular}{ccc}
$\begin{array}{l}\text { Macrophages } \\
\text { incubated with }\end{array}$ & $\begin{array}{l}\text { MFI } \\
(\log )^{\mathrm{a}}\end{array}$ & $\begin{array}{l}\text { FI } \\
\text { index }^{\mathrm{b}}\end{array}$ \\
\hline $\begin{array}{c}\text { M.lepraemurium, } \\
8 \mu \mathrm{g} / \text { dish }\end{array}$ & 27.6 & \\
40 & 31.7 & 0.90 \\
200 & 22.6 & 1.03 \\
1,000 & 14.0 & 0.74 \\
M.intracellulare, & & 0.46 \\
8 & 32.2 & \\
40 & 31.6 & 1.05 \\
200 & 26.5 & 1.03 \\
1,000 & 20.5 & 0.86 \\
M.gordonare, & & 0.67 \\
8 & 28.3 & \\
40 & 29.6 & 0.92 \\
200 & 23.4 & 0.96 \\
1,000 & 13.8 & 0.76 \\
Lymphokine & 67.2 & 0.45 \\
Medium & 30.7 & 2.19 \\
\hline
\end{tabular}

${ }^{a}$ Channel number of MFI (Mean Fluorescence Intensity) by a flow cytometry analysis.

'Index of FI (Fluorescence Intensity)

$=($ MFI of macrophages incubated with sample) $/$ MFI of macrophages incubated with medium). 
(data not shown).

The logarismic mean fluorescence intensity (MFI) of these normal cells was 30.7 (table 3). On the other hand, macrophages incubated for 3 days with three kinds of heat-killed mycobacteria, $M$. lepraemurium, $M$. intracellulare, and $M$. gordonare, all showed lower values of MFI, indicating the reduced expression of Ia. For easy understanding, the results are summarized as a fluorescence intensity (FI) index based on the consideration of fluorescence intensity of macrophages cultured in medium only as 1 (table 3 ).

Down-regulation of Ia expression in macrophages from MRL/lpr mice by mycobacteria. Since peritoneal macrophages of $\mathrm{MRL} / \mathrm{lpr}$ mice express enhanced Ia on cell surface without any kinds of cytokine stimulations in vitro $^{(7)}$, we employed macrophages of these mice as a source of Ia-positive cells. Peritoneal cells from MRL/lpr mice of 3 months old were harvested by intraperitoneal lavage and were seeded on dishes. After $3 \mathrm{hr}$ incubation, nonadherent cells were washed out for purifying adherent cells. Over 95\% of these adherent cells were macrophages as characterized by positive staining of esterase and by phagocytic activity of fluorescence-labelled latex beads. By flow cytometry analysis, the cells already possessed enhaced Ia expression on the surface (data not shown). The results in figure 1 show the suppressed Ia expression after 3 day incubation of these macrophages with heat-killed mycobacteria. Cells incubated only in medium, on the other hand, preserved high levels of Ia expression during the culture period. Peritoneal macrophages from $\mathrm{MRL} / n$, which do not develop the disease, expressed low Ia expression during the culture period (figure 1).

Enhanced Ia expression in macrophages by lymphokine or IFN treatment and inhibited expression by incubation with mycobacteria.

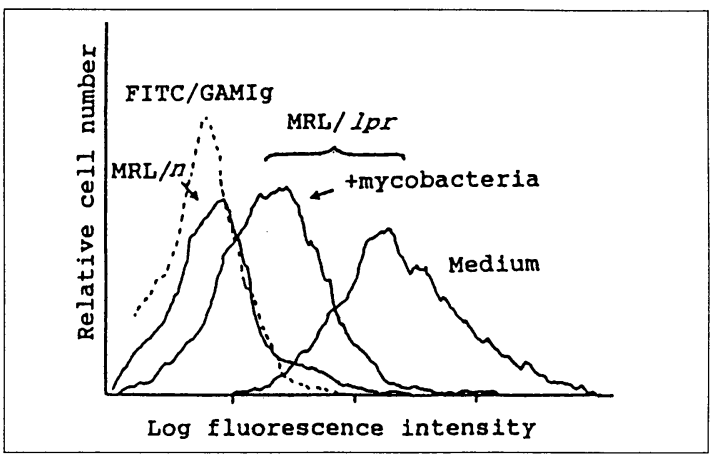

Figure 1. Reduced Ia expression in macrophages from MRL/lpr mice following incubation with mycobacteria. Peritoneal macrophages from MRL/ $l p r$ or MRL/ $n$ mice were cultured for 3 days follwed by analyzed Ia expression. In some experiments, heat-killed M.intracellulare were added in culture at the beginning.

Induction of Ia in macrophages by cytokine stimulation was analyzed. Peritoneal macrophages from $\mathrm{C} 3 \mathrm{H} / \mathrm{HeJ}$ mice were cultured with lymphokine-rich culture supernatnat of spleen

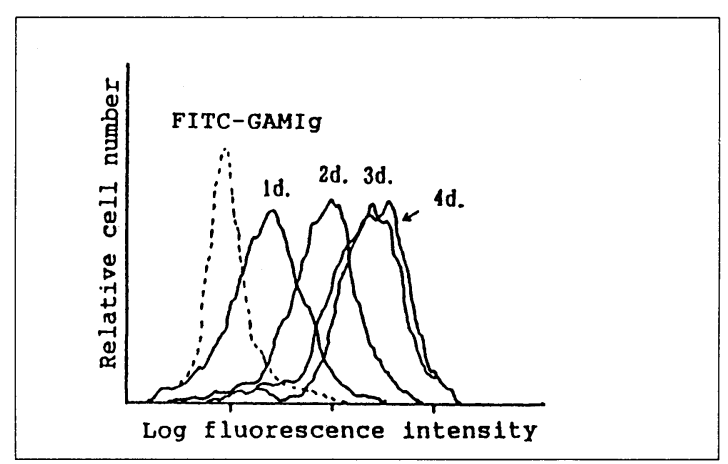

Figure 2. Enhanced Ia expression in peritoneal macrophages incubated with lymphokine. Peritoneal macrophages from $\mathrm{C} 3 \mathrm{H} / \mathrm{HeJ}$ mice were cultured with supernatant obtained from con A-stimulated spleen cell culture. At various days after incubation, the cells were collected and analyzed for their Ia expression.

cells (LK). The results in figure 2 show that Ia expression was augmented day by day, and maximum expression was observed at 3 days. The day for analysis of Ia expression was therefore settled at 3 days. In the case of LK preparation, the Ia enhancing activity is now believed to be mainly mediated by $\operatorname{IFN} \gamma$. Hence, IFN $\gamma$ was applied to examine the induction of Ia in macrophages. The results are 


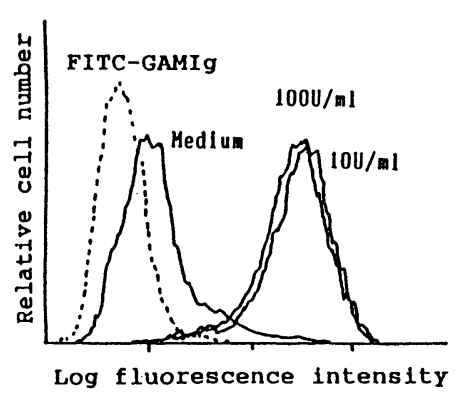

\begin{tabular}{c|c}
$\begin{array}{c}\text { IFN } \gamma \\
\mathrm{U} / \mathrm{ml}\end{array}$ & $\begin{array}{c}\text { Mean Fluorescence } \\
\text { intensity(lin.) }\end{array}$ \\
\hline 0 & 29 channel \\
1 & 324 \\
10 & 365 \\
100 & 345 \\
FITC- & 8 \\
GAMIg &
\end{tabular}

Figure 3. Enhanced Ia expression in IFN -treated macrophages. Peritoneal macrophages from $\mathrm{C} 3 \mathrm{H} /$ HeJ mice were cultured with several doses of murine recombinant IFN $\gamma$ for 3 days. Ia expression in the cells was then analyzed by a flow cytometry. Values indicated in the lower table was calculated as a mean fluorescence intensity based on linear fluorescence intensity of each sample.

shown in figure 3 . In our system, only $1 \mathrm{unit} / \mathrm{ml}$ of IFN $\gamma$ was enough to induce strong Ia expression. Ten units $/ \mathrm{ml}$ of recombinant murine IFN $\gamma$ was selected for later use.

Macrophages were incubated with $M$. intracellulare in the presence of IFN $\gamma$ for 3 days followed by analysis of Ia expression. As shown

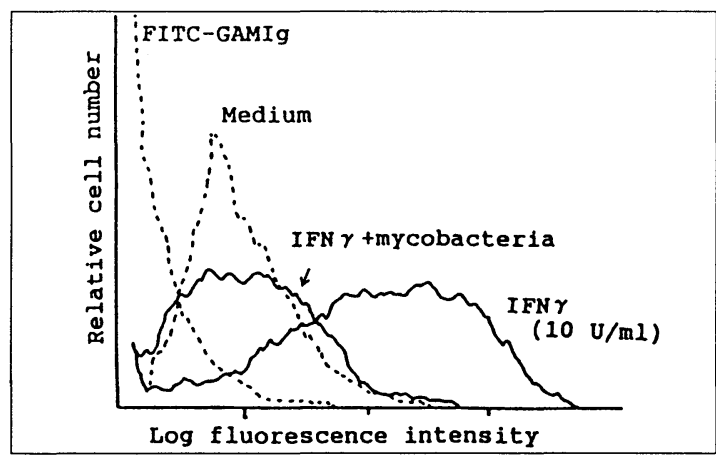

Figure 4. Inability of Ia expression in mycobacteriumphagocytized macrophages. Peritoneal macrophages from $\mathrm{C} 3 \mathrm{H} / \mathrm{HeJ}$ mice were cultured with IFN $\gamma$ in the presence of heat-killed mycobacteria for 3 days. Ia expression in macrophages were then analyzed. in figure 4, IFN $\gamma$-treated macrophages exhibited a high level of Ia expression. Interestingly, if the cells were incubated with mycobacteria, Ia expression was strongly blocked.

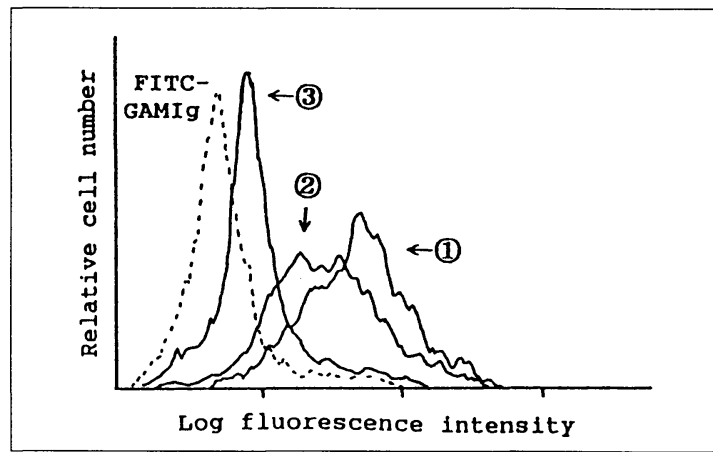

Figure 5. Effect of supernatant of macrophages incubated with mycobacteria on Ia induction in IFN $\gamma$-treated macrophages. Peritoneal macrophages from $\mathrm{C} 3 \mathrm{H} / \mathrm{HeJ}$ mice were cultured with mycobacteria for 3 days. Then the supernatant was harvested, dialyzed, and added to normal macrophage culture with $10 \mathrm{U} / \mathrm{ml}$ of recombinant murine IFN $\gamma$. (1),10 U/ml of IFN $\gamma$; (2), $10 \mathrm{U} / \mathrm{ml}$ of IFN $\gamma$ in the presence of supernatant obtained from macrophages incubated only with medium; (3), $10 \mathrm{U} / \mathrm{ml}$ of IFN $\gamma$ and supernatant obtained from macrophages incubated with heat-killed $M$. intracellulare.

Next, macrophages were incubated concomitantly with normal or mycobacteriumcontaining medium for 3 days and the supernatants were harvested. After centrifugation and dialysis of the supernatants, normal macrophages were incubated with IFN $\gamma$ in the presence of the supernatants. Ia expression was then analyzed after 3 days. The results in figure 5 indicate that few suppression of IFN $\gamma$-induced Ia was observed in macrophages incubated with supernatant obtained from macrophages cultured only with medium. On the contrary, strong suppressive activity existed in the supernatant of macrophages cultured with mycobacteria (figure 5).

\section{DISCUSSION}

Macrophages play a regulartory role in immune responses by production of cytokines, 
interleukin-1 and tumor necrosis factor ${ }^{(2)}$, and by presentation of antigens to $T$ cells, which recognize antigen on the surface in association with Ia molecules ${ }^{(3)}$. To explore the role of macrophages in immune response on mycobacterial infections including leprosy disease, we used three kinds of mycobacteria, such as $M$. lepraemurium, $M$. avium and $M$. gordonare, and examined macrophage response to these mycobacteria in vitro. We here again demonstrated IL-1 and TNF releases by mouse macrophages following the incubation with heat-killed mycobacteria ${ }^{(8)}$. Furthermore we have observed TNF production by both human and mouse macrophages during the course of incubation with $M$. leprae (Fukutomi et al. in preparation).Presumably these observations are common features of macrophage response to mycobacteria. It has been reported that various mycobacterial constituents, such as cord factor, muramyl dipeptide (MDP), and LAM etc, can stimulate macrophages to produce cytokines ${ }^{(9,10)}$. Macrophage production of IL-1 and TNF following the incubation with heat-killed mycobacteria therefore would originate from response against these mycobacterial constituents.

Macrophages phagocytizing mycobacterial organisms acquired accelerated utilization of glucose, compared to normal macrophages (Table 2). Since the enhancement of glucose utilization is one of the characteristics of macrophages in the activation state ${ }^{(11)}$, it is likely that mycobacterium-phagocytizing macrophages were at least metabolically activated.

Peritoneal macrophages from normal mice ordinary express a low amount of Ia ${ }^{(12)}$. This was completely inhibited after the incubation with mycobacteria (table 3 ). In addition, similar results were obtained for macrophages of $\mathrm{MRL} / \not p r$ mice. MRL/lpr mice develop a lupus -like syndrome characterized by antibodies to nucleic acids and by immune-complex glomer- ulonephritis ${ }^{(7)}$. Peritoneal macrophages from these mice were reported to express high Ia expression preceding to $\mathrm{IFN}_{\gamma}$ treatment in vitro ${ }^{(7)}$.We studied on the change in the extent of the expression of Ia on macrophages from the MRL/lpr mice.It was found that peritoneal macrophages from MRL/lpr mice incubated with heat-killed mycobacteria also indicated reduced Ia after 3 days (figure 1). IFN $\gamma$-induced increase in the Ia expression was also suppressed in the presence of mycobacteria (figure 4). Sibley et al. also reported that $M$. leprae-ingesting macrophages exhibited nonresponsiveness to $\operatorname{IFN} \gamma$, a cytokine which generally augments macrophages functions related to intracellular killing of parasites and the expression of Ia ${ }^{(13)}$. In any case, suppressed expression of Ia following phagocytosis of mycobacteria occurres in macrophages in any conditions.

Recently it has been pointed out LPS contamination in certain materials, specimens, and culture media in vitro study of macrophage functions, and it may affect the experimental results. LPS is a potent stimulator for macrophage cytokine producing ability but an inhibitor of IFN $\gamma$-mediated Ia induction ${ }^{(14)}$. The LPS contamination easily occurs during the preparation of specimens due to its ubiquitous existence. Therefore, there is a possibility for LPS contamination in our mycobacterial preparation. $\mathrm{C} 3 \mathrm{H} / \mathrm{HeJ}$ mouse, a LPS-non responder ${ }^{(15,16)}$, generally used for control experiments which are required to eliminate LPS side effects. Thus we employed macrophages from this strain of mouse as yet observed suppressed Ia following the incubation with mycobacteria, indicating that the observed suppression was not due to LPS contamination in our mycobacterial preparations.

The culture supernatant of macrophages stimulated with mycobacteria also passessed activity to inhibit $\mathrm{LK}$ - or IFN $\boldsymbol{\gamma}$-mediated en- 
hancement of Ia expression in normal macrophages. There is a report that TNF is one of the factors that suppresses Ia expression (17), and one or more proteins, which inhibit IFN $\gamma$ induced Ia expression, were produced early after treatment with maleylated-BSA or LPS ${ }^{(18)}$. In addition, we observed that IFN $\gamma$-induced Ia expression was strongly inhibited by TNF (Fukutomi et al., manuscript in preparation). Cyclooxygenase product, PGE2, which is produced by macrophages after stimulation, is also an inhibitor of IFN $\gamma$-induced Ia expression ${ }^{(19)}$. Supernatant used in this study, which had been dialyzed to remove small molecules including $\mathrm{PGE}_{2}$, still exhibited the suppressive activity, thereby suggesting the present suppressive factor (s) of macrophage Ia expression is not $\mathrm{PGE}_{2}$.

Similar suppression of Ia expression in macrophages was reported by Mshana et al. for $M$. kansasi ${ }^{(20)}$. They reported that the suppression was observed only in the case of live bacteria. Live mycobacteria suppressed Ia expression without exerting no cytotoxicity. They heated mycobacteria at $100{ }^{\circ} \mathrm{C}$ for 30 to $45 \mathrm{~min}$ to obtain heat-killed preparation. We just heated at $121{ }^{\circ} \mathrm{C}$ for $5 \mathrm{~min}$. Perhaps the difference between our and their results may be caused by the different condition of heat treatment. Namely, as they mentioned, longer treatment may alter the nature of bacterial components which are able to stimulate macrophages.

IL -1 , initially described as lymphocyte activating factor (LAF), has a pivotal immunostimulant role since it can enhance both immunoglobulin production by B lymphocytes and activation of $\mathrm{T}$ lymphocytes ${ }^{(2)}$. IL-1 is also known to play an important role in granuloma formation in a model system, by promoting granuloma formation ${ }^{(21,22)}$. In addtion, IL-1 activates macrophages, all functions of which activity are closely related to the protective immunity of host against bacterial infection ${ }^{(23)}$.
Similarly, TNF plays an important role in granuloma formation ${ }^{(24)}$. TNF displays some roles in the host resistance to bacterial infection, by activating macrophage cell functions, etc. ${ }^{(25)}$. From this point of view, supernatantinduced suppression of Ia expression observed here is the other side of the coin in immune response on mycobacterial infection. Suppressed Ia expression in macrophages results in their loss of antigen presenting ability, suggesting that macrophages may lost certain kinds of cell functions without showing any decreases in their cytokine production.

As mentioned above, IL-1 and TNF mainly play as activators for macrophages rather than as inhibitors, and are probably involved in anti $-M$. leprae response in leprosy patients. In local lesion, especially in LL patients, there are many loads of bacteria in macrophages. Therefore macrophages in the lesion could produce IL-1 and TNF in response to the stimulatory signals given by bacteria as we observed in this in vitro system. It is of interest to note the findings of Yamamura et al. that there was no detectable level of IL-1 and TNF in lesions of LL patients even by using PCR technique ${ }^{(26)}$. As they mentioned in the report, immunosuppressive cytokine(s) such as IL-10 and TGF beta, which are synthesized by $\mathrm{T}$ lymphocytes and macrophages, may inhibit the production of IL-1 and TNF by macrophages ${ }^{(26,27,28)}$. On the other hand, Sibley et al. reported that macrophages gorged with M. leprae were refractory to be activated by IFN ${ }^{(13)}$. There also may be a possibility, that the macrophages phagocytized bacteria, released cytokines in a transient fashion and thereafter they lost responsiveness to any cytokine production-inducing signals by some unknown mechanisms other than cytokine-mediated suppression.

In conclusion, it is thought that macrophage responses to mycobacteria may induce changes in a variety of characteristic features of host 
immune response. Moreover, cytokines released by macrophages as well as by $T$ lymphocytes could play a crucial role in host defence against mycobacterial infections.

\section{ACKNOWLEDGEMENTS}

A part of this study was supported by a grant of US-Japan Cooperative Medical Science Program. The authors also wish gratefully to acknowledge the Sasakawa Memorial Health Foundation for the financial support for this study.

\section{REFERENCES}

1) Orme, I. M. : "Immunity to mycobacteria" In Current opinion in immunology. Alt, F., and Marrack,P. (eds), Current biology Inc., 5(No. 4): 497-502 (1993).

2) Dinarello, C. A.: Interleukin-1 and its biologically related cytokines. Advances in Immunology. 44, 153-205 (1989).

3 ) Murphy, E. D.: Lymphoproliferation (lpr) a mutant gene in strain MRL inducing murine lupus in Immunologic Defects in Laboratory Animals, Vol. 2. Gershwin, M. E., and Merchant, B (eds), Plenum Press, New York, p.143 (1981).

4) Mizel, S. B.: Physicochemical characterization of lymphocyte activating factor (LAF). J. Immunol. 122:2167-2172 (1985).

5 ) Aggarwal, B. B., Kohr, W. J., Hass, P. E., Moffat, B., Spencer, S. A., Henzel, W. J., Bringman, T. S., Nedwin, G. E., Goeddel, D. W., and Harkins, R. N.: Human tumor necrosis factor. J. Biol. Chem. 260: 2345-2354 (1985).

6 ) Ryan, J. L., Glode, L. M., and Rostreich, D. L.: Lack of responsiveness of $\mathrm{C} 3 \mathrm{H} / \mathrm{HeJ}$ macrophages to lipopolysaccharide: The cellulr bases of LPS-stimulated metabolism. J. Immunol. 122:932-935 (1979).

7 ) Kelley, V. E. and Roths, J. B.: Increase in macrophage Ia expression in autoimmune mice: Role of the $l p r$ Gene. J. Immunol. 129: 923-925 (1982).

8 ) Fukutomi, Y., Inui, S., and Onozaki, K.: Monokine production by mouse Peritoneal macrophages after phagocytosis of mycobacteria. Jpn. J. Leprosy 61: 92-97 (1992). 9 ) Wahl, S. M. , Wahl, M. L., McCarthy, J. B., Chedid, L., and Mergenhagen, S. E.: Macrophage activation by mycobacterial water soluble compounds and synthetic muramyl dipeptide. J. Immunol. 122: 2226-2231 (1979).

10) Moreno, C., Taverne, J., Mehlert, A., Bate, C. A., Brealey, R. J., Meager, A., Rook, G. A., and Playfair, J. H.: Lipoarabinomannan from Mycobacterium tuberculosis induces the production of tumour necrosis factor from human and murine macrophages. Clin. Exp. Immunol. 76: 240-245 (1989).

11) Onozaki, K., Haga, S., Ichikawa, M., Homma, Y., Miura, K., and Hashimoto, T.: Production of an antibody against guinea pig MIF. III. Biological activity of MIF recovered from immunoadsorbant column chromatography. Cell Immunol. 61: 165-175 (1981).

12) Beller, D. I. and Ho, K.: Regulation of macrophage populations V. Evaluation of the control of macrophage Ia expression in vitro. J. Immunol. 129: 971-976 (1982).

13) Sibley, L. D., and Krahenbuhl, J. L.: Induction of unresponsiveness to gamma interferon in macrophages infected with Mycobacterium leprae. Infect. Immun. 56: 1912-1919 (1988).

14) Steeg, P. S., Johnson, H. M. , and Oppenheim, J. J.: Regulation of murine macrophage Ia antigen expression by immune interferon-like lymphokine: inhibitory effect of endotoxin. J. Immunol. 129: 2402-2406 (1982).

15) Skidmore, B. J., Chiller, J. M. , and Weigle, W. O.: Immunologic properties of bacterial lipopolysaccharide (LPS). IV. Cellular basis of the unresponsiveness of $\mathrm{C} 3 \mathrm{H} / \mathrm{HeJ}$ mouse spleen cells to LPS-induced mitogenesis. J. Immunol. 
118: 274-281 (1977).

16) Chedid, L., Parant, M. , Damais, C., Parant, F., Juy, D., and Galelli, A.: Failure of endotoxin to increase nonspecific resistance to infection of lipopolysaccharide low-responder mice. Infect. Immun. 13: 722-726 (1976).

17) Zimmer, T., and Jones P. P.: Combined effects of tumor necrosis factor- $\alpha$, prostaglan$\operatorname{din} \mathrm{E}_{2}$, and corticosterone on induced Ia expression on murine macrophages. J. Immunol. 145: 1167-1175 (1990).

18) Hamilton, T. A., Gainey, P. V., and Adams, D. O.: Maleylated-BSA suppresses IFN gamma -mediated Ia expression in murine peritoneal macrophages. J. Immunol. 138:4063-4068 (1987).

19) Synder, D. S., Beller, D. I., and Unanue, E. R.: Prostaglandins modulate macrophage Ia expression. Nature 299 (9): 163-165 (1982).

20) Mshana, R. N., Hastings, R. C., and Krahenbuhl, J. L.: Infection with live mycobacteria inhibits in vitro detection of Ia antigen on macrophages. Immunobiol. 177: 40-54 (1988).

21) Kobayashi, K., Allred, C., Cohen, S., and Yoshida, T.: Role of interleukin 1 in experimental pulmonary granuloma in mice. J. Immunol. 134: 358-364 (1985).

22) Kasahara, K., Kobayashi, K., Shikama, Y., Yoneya, I., Soejima, K., Ide, H., and Takahashi, T.: Direct evidence for granuloma-inducing activity of interleukin 1. Am. J. Pathol. 130: 629
-638 (1988).

23) Hoover, D. L., and Meltzer, M. S.: "Lymphokines as monocyte activators" In Human monocytes. Zembala, M. , and Asherson, G. L. (eds) Academic Press, p.151-160 (1989).

24) Kindler, V., Sappino, A., Grau, G. E., Piguet, P., and Vassalli, P.: The inducing role of tumor necrosis factor in the development of bactericidal granulomas during BCG infection. Cell 56: 731-740 (1989).

25) Old, L. J.: "Tumor necrosis factor" In Bonavida, B. and Granger, G. (eds): Tumor necrosis factor: Structure, mechanisms of action, role in disease and therapy. Karger, Basel, p.1-30 (1990).

26) Yamamura, M. , Uyemura, K., Deans, R. J., Weinberg, K., Rea, T. H., Bloom, B. R., and Modlin, R.: Defiining protective responses to pathogens: Cytokine profiles in leprosy lesions. Science 254: 277-282 (1991).

27) Bodgan, C., Vodovots, Y., and Nathan, C.: Macrophage deactivation by interleukin-10. J. Expl. Med. 174: 1549-1555 (1991).

28) Espevik, T., Figari, I. S., Shalaby, M. R., Lackides, G. A., Lewis, G. D., Shepard, H. M. , and Palladino, M. S. $\mathrm{J}_{\mathrm{R}}$.: Inhibition of cytokine production by cyclosporin A and transforming growth factor beta. J. Expl. Med. 166: 571-576 (1987). 


\title{
抗酸菌と共に培養したマクロファージ上Ia分子発現の抑制調節機構
}

\section{福富康夫 ${ }^{1 *}$, 乾左徒子 ${ }^{2)}$, 小野崎菊夫 ${ }^{3)}$, 與儀ヤス子 ${ }^{1)}$, 皆川文重 ${ }^{1)}$}

\author{
1) 国立多摩研究所 \\ 2）筑波大学基礎医学系微生物 \\ 3）名古屋市立大学薬学部衛生化学教室
}

$$
\text { キーワード：マクロファージ, IL-I, TNT, Ia, ミコバクテリア }
$$

マクロファージがさまざまな刺激を受けるとサ イトカインを産生することが知られている。本研 究では, M. lepraemurium, M. intracellure, $M$. gordonareを用いて, in vitroでC $3 \mathrm{H} / \mathrm{H}$ e 並び にC $3 \mathrm{H} / \mathrm{H}$ e J マウス由来腹腔マクロファージ と共に培養し 3 日目の培養上清中のサイトカイン 活性を調べた。その結果, これら抗酸菌を食食し たマクロファージからインターロイキンー 1 と腫 瘍壊死因子（T N F） が放出されることを観察し た。その放出量は加えた菌量に比例した。さらに, 以前から報告されているごとく，マクロファージ をインターフェロン $\gamma(\mathrm{I} \mathrm{F} \mathrm{N} \mathrm{\gamma})$ と共に培養する と細胞表面上に強いIa発現が観察される。しかし,
抗酸菌を領食したマクロファージではＩＦＮとに よるIa発現は抑制された。同様に, MR L / lpr ウスの腹腔マクロファージはIaを強く発現してい るが, 抗酸菌と共に培養すると 3 日後には発現が 抑制された。興味あることに，抗酸菌と共に培養 したマクロファージの培養上清を I F N $\gamma$ 存在下 で培養してもIa抑制活性が見られた。

$$
\text { これらの結果は, マクロファージにおけるサイ }
$$
トカイン産生と細胞表面Ia発現の抑制は同時に起 こる現象であることを示唆している。そして, Ia発 現抑制機構の少なくとも一部分は抗酸菌会食マク ロファージから産生される抑制因子によって担わ れていることが判明した。 